\title{
Exploring Salient Socio-Linguistic Features of African-American English Vernacular
}

\author{
Rula M. Zughoul ${ }^{1}$ \& Abdel-Rahman H. Abu-Melhim ${ }^{1}$ \\ ${ }^{1}$ Department of English Language and Literature, Irbid University College, Al-Balqa' Applied University, Irbid, \\ Jordan \\ Correspondence: Prof. Abdel-Rahman Abu-Melhim, Department of English Language and Literature, Irbid \\ University College, Al-Balqa’ Applied University, Irbid, Jordan. Tel: 962-772-241-740. Fax: 962-27-254-635.
}

Received: February 21, 2016

Accepted: March 11, 2016

Online Published: March 15, 2016

doi:10.5430/elr.v5n1p32

URL:http://dx.doi.org/10.5430/elr.v5n1p32

\begin{abstract}
This study aimed to highlight the distinguishing socio-linguistic features of African-American English Vernacular. It focused on this variety in terms of different theories concerning its origin and provided a relatively detailed description of the structure of this dialect. Furthermore, the study attempted to discuss the most common educational controversies surrounding the use of this particular variety of English as it is used in America today. Related literature was first reviewed especially that which is directly related to various theories concerning the origin of African-American English Vernacular and how this dialect has developed as a major dialect of American English over time in the United States. Empirically, the data collection process involved eliciting spoken data in naturally occurring circumstances from African-American informants residing in the state of Texas in 2014. The study included twenty male and female informants enrolled at Texas A \& M University, College Station in both graduate and undergraduate programs. The researchers used both personal and telephone interviews in the data collection process after obtaining the personal written consent of the informants in both cases. The data were then carefully reviewed and analyzed in an attempt to determine the most salient grammatical, phonological, lexical, and social features of AAEV as it is used in America today. Although a strong correlation between AAEV and Standard American English (SAE) exists, AAEV's unique origins remain unknown. AAEV is similar to Creole language forms used by many the world over. Phonology traits that differentiate AAEV from other language forms include: Word-final devoicing, reduction of certain diphthong forms to monophthongs. AAEV's vocabulary is similar to that of Southern informal American dialects. In fact, AAEV users are typically bi-dialectal, meaning that they code-switch between AAEV and SAE often. Debates over AAEV's use have formed controversial socio-cultural settings with regard to education, particularly that of African-American youth. For example, the Resolution of Oakland held that AAEV had little to do with SAE or any other European language but rather originated from West-African languages. Despite all the controversies surrounding AAEV in terms of its origin or educational role in America today, it might be safe to propose that this particular dialect of American English-call it what you wish-will only receive more attention in modern linguistics and acquire gradual socio-linguistic prestige in the $21^{\text {st }}$ century. This assumption is primarily based on the overwhelming political changes in the United States today.
\end{abstract}

Keywords: African-American English Vernacular, Socio-linguistics, Dialectology, American education

\section{Introduction}

\subsection{Definition of AAEV}

AAEV (African-American English Vernacular), is an African-American language form similar to SAE (Southern American English). This language form is also referred to by some as jive or Ebonics. Its linguistic structure relates strongly to that of SAE spoken by African-Americans and non-African-Americans throughout the US. According to Labov, "There is little regional variation among speakers of AAVE" (Labov, 2001, 506-508).

Creolists such as Rickford (1999), Dillard (1972) and Stewart (1975) agree that because Creole language forms spoken by African-Americans throughout the US is so similar to Creole language forms spoken throughout the world, AAEV should be considered Creole itself. (Wardhaugh, 2002). Others disagree, however, citing a failure to establish significant correlations among these particular Creole language forms (Poplack \& Tagliamonte, 2006, Pullum 1997). All linguists seem to agree on one thing, however - that AAEV finds its roots in West-African language forms 
(Poplack \& Tagliamonte, 2006). In line with other language forms that are used throughout the US, status, age, situation and topic influence the use of AAEV. AAEV differs, however, in that it is used heavily as-is in much African-American literature.

\subsection{Ethnic Background}

Language variation in a speech community may result from diversification in ethnic backgrounds. Because of speech acquisition processes that occur as a result of language transmission by people who migrate to one area, for instance, including language carried over by their children, certain language form characteristics become more salient than others. This is especially the case when the dominant social group speaks a specific language form more heavily than others. For our purposes, this means that AAEV is not only wide-spread but also cross-cutting with various differences associated to regions. Moreover, the defining characteristics of AAEV are more salient because of dissimilation associated with segregation historically experienced by African-Americans. Indeed, such social processes cause language forms to preserve certain qualities so as to not assimilate. The speech form that results can become viewed by the mainstream as "bad English". For example, the common omission of the copula by many African-Americans might cause the mainstream to consider this as improper English. The fact is, however, that many markedly prominent languages, such as Russian and Arabic, do the same thing. Indeed, the structure of their copula use does not differ from that of AAEV, and therefore should not be considered as poor English any more than those language forms. They simply divert from SAE.

A similar point of criticism often made by the educational system is the frequent use of double-negative language structures. For example, "I ain't know that". Such educators typically consider these language structures to be illogical. If that is indeed the case, however, the French, which often uses a double negative, for example "il NE sait RIEN" (He doesn't know anything), and English (old): "Ie NAHT singan NE cuoe" (I didn't know how to sing), are similarly illogical. On the contrary, however, this article posits that such uses of double-negatives in fact provide more emphasis on the negative aspect of the structure, thereby making it more definable as a feature of dialectics (Yule, 1985).

\subsection{Origins of $A A E V$}

Although SAE and AAEV are similar, AAEV's origins still remain debated. One thing is agreed upon among linguists, however - that AAEV and SAE share similar language structure characteristics. Some posit that AAEV rose to prominence and common use through the slave trade - specifically through the need to speak with one another and with slaveholders. This language-formation process resulted in pidgins, which are mixes of multiple languages in this case inherited from Yoruba, Dogon, Akan, Wolof, Twi, Hausa, Kimbundu, Bambara and Igbo. Thus, pidgins come as a result of close-contact amongst language users from different communities. Therefore, linguists are supported in their theory that the slave trade could have led to such language-formations although language mixing was minimal on board of a slave-ship (Dillard, 1972). In fact, until approximately 1700, native African slave languages preserved their original usages. This changed when Wolof became a precursor to pidgin formation among slaves - evidenced through works such as The Life of Colonel Jacque by Daniel Defoe.

Around the American Revolution era, different language forms used amongst slaves had not been reciprocally comprehensible (Dillard, 1972).It was not till the Civil War that slave-language became compressible to Southern Whites. As an example, Higginson, in his 1870's Army Life in an African-American Regiment discussed various aspects of soldier-language that had differing AAEV phonology. Post-abolition, some went back to their West-African origins, assimilating their Creole there. This was particularly the case for Africans in west Cameroon, and until now the African dialects used there have great correlations with AAEV.

East Anglian origins theory posits that since African-Americans obviously did not migrate to the United States from East Anglia, the East Anglian theory can only suppose that the African-Americans got their language forms entirely from Whites. In Dillard (1972), Harrison reports that: "It must be confessed, to the shame of the white population of the South, that they perpetuate many of these pronunciations in common with their Negro dependents; and that, in many places, if one happened to be talking to a native with one's eyes shut, it would be impossible to say whether a Negro or a white person were responding" (p.232). Harrison added that:"Negro speech and White speech are never distinguishable in the South" (Dillard, 1972, p.187).

\section{Purpose}

This study underlines the distinguishing language form characteristics of AAEV, which is used by eighty-percent of African-Americans today. Specifically, this study evaluates the salient features of AAEV in light of different theories concerning its origin, the nature of AAEV, and provides a relatively detailed description of the structure of this 
dialect. Furthermore, the study attempts to discuss the most common educational controversies surrounding the use of this particular variety of English as it is used in America today.

\section{Data Collection}

To achieve the aims of this study, related literature was first reviewed especially that which is directly related to various theories concerning the origin of African-American English Vernacular and how this dialect has developed as a major dialect of American English over time in the US. Empirically, the data collection process involved eliciting spoken data in naturally occurring circumstances from African-American informants residing in the state of Texas in 2014. The study included twenty male and female informants enrolled at Texas A \& M University, College Station in both graduate and undergraduate programs. The researchers used both personal and telephone interviews in the data collection process after obtaining the personal written consent of the informants in both cases. The data were then carefully reviewed and analyzed in an attempt to determine the most salient grammatical, phonological, lexical, and social characteristics of AAEV used in America today.

\section{AAEV Language Form Traits}

Analysis revealed that AAEV holds similar language form traits with other Creole language forms spoken the world over. This is particularly the case with West-African languages in terms of grammatical structure, pronunciation and lexicon. Also, AAEV is similar to the SAE language form. In fact, many linguists argue that SAE has adopted much of its characteristic usage from AAEV itself; for example, with the dropping of are-is (Labov, 1972).

Language traits that differentiate SAE from AAEV are:

1. Differing lexicon verb-tense: AAEV originally added many West-African terms to SAE, including, yam, banjo, goober, and gumbo.

2. Differences in language trait-patterns, a variety of which find their origins in West-African dialects and Creole language forms. These also reappear in Newfoundland English and other English language forms influenced by West-African languages.

\subsection{Grammatical Features}

\subsubsection{Phonology}

"The near uniformity of AAEV pronunciation, despite a vast geographical area, may be due in part to relatively recent migrations of African-Americans out of the South as well as to long-term racial segregation" (Wardhaugh, 2002, p.339). Phonology-aspects that differentiate AAEV from SAE are:

1. The devoicing of word-endings; for example, of /g/, /d/ and /b/ - cub would sound like cup (Green, 2002).

2. The changing of diphthongs to monophthong forms; for example, /ai/ becomes/a:/(Labov, 1972).

3. Failure to use dental-fricatives $/ \theta /$ (for example, the th in thin) in addition to / $/$ / th as in then; (Green, 2002, p.117).

4. Actualization of final- $n g / \mathrm{n} /$, velar-nasal, given the alveolar-nasal/n/'s function in morphemes and content-morphemes with 'ing'; as an example, shopping sounds like shoppin.

5. The cluster reduction of final-consonants; for example, /st/, /sk/ and /sp/ become deleted (Labov, 1972).

6. Similar to $\mathrm{SAE}, / \mathrm{n} /, / \mathrm{m} /$ and $/ \mathrm{y} /$ make pin-and-pen homophone sounds. 


\subsubsection{Copula-Marking}

AAEV is distinct in its excessive use of be copula in marking phrases. Table 1 below illustrates this phenomenon:

Table 1. Examples from naturally occurring conversations

\begin{tabular}{lll}
\hline Example & Name & Meaning / Notes \\
\hline She workin'. & Simple-progressive & She is working (currently). \\
She always be workin'. & continuative aspect & She often works. \\
She stay workin'. & Intensified continuative & She is always working. \\
She been workin'. & Perfect-progressive & She has been working. \\
She always had dat job. & Remote-phase & She has had that job for a long time and still has it. \\
She done worked. & Emphasized perfective & She has worked (Green, 2002, p.60). \\
She finna go to work & Immediate future & She is about to go to work. \\
\hline
\end{tabular}

\subsubsection{Remote Phase Marker}

The characteristic associated with 'been', such as remote-phase, remote-past and perfect-phase is stressed for the purpose of differentiating it from un-stressed markers (Rickford, 1999). For example, been sounds like BIN (Green 2002).

Been's role in non-stative verbs is that it puts the action in past-tense, or completes the action. When it is used with gerund formulations, however, it can signify that what seem to be past actions are in fact occurring now (Rickford, 1999). For example, I been bought her clothes refers to "I bought her clothes a long time ago" and I been buyin' her clothes refers to "I've been buying her clothes for a long time".

\subsubsection{Negation}

Additionally, negative-usages are formulated in a manner other than in SAE (Howe \& Walker, 2000):

- $\quad$ Aint's use as a general-negative (Labov, 1972, p.284).

- $\quad$ "double-negation", or negative concord

- Negative-construction: As an example, Ain't much goin' on here (Winford, 1992)

\subsection{Social Features}

AAEV's anti-assimilation to SAE any other standard-language forms is the result of societal processes of segregation that forged pride, solidarity and a sense of identity among African-Americans. According to Smitherman, AAEV is "intricately bound up with his or her sense of identity and group consciousness", (Smitherman, 1977, p.71). Moreover, it has made it through the years by isolating itself from SAE either by group-choice or through marginalization by the societal mainstream. Nonetheless, AAEV -users are mostly bi-dialectal, often code-switching between SAE and AAEV. This adaption applies linguistically in different social settings. Generally speaking, "the degree of exclusive use of AAEV decreases with the rise in socio-economic status although it is still used by even well-educated African-Americans", (Coulmas, 2005, p.177).

Code-switching prevalence, moreover, signifies that SAE and AAEV are treated differently, whereas the latter is typically shunned as educationally-lacking. Consequently, this is why it is often referred to as 'bad' or 'lazy' English (Labov, 1997).

\section{Educational Implications}

AAEV -usage has not been met without controversy. Of particular relevance is the role that it should have in public education, in addition to its position in American society. While some representatives from the education field have tried to eliminate its use of AAEV, arguing that it is intrinsically-deficient as speech, (Wardhaugh, 2002, p.343).

Indeed, it has been posited that AAEV -incorporation into the school-system only further hinges African-American's progress. In fact, "The harshest criticisms of AAVE have come from other African-Americans" (Green, 2000, p.200). Furthermore, as Quinn writes, "African-American critics of African-American English vernacular use all the 
different arguments of the white critics, and spare us the more or less open embarrassment that all white Americans feel when publicly criticizing anything or anyone Black. So, of course, they can be even more wrong-headed and self-righteously wrong-headed than anyone else..." (Quinn, 1982, pp.150-151).

Others, however, have fought for its right to be preserved. For example, the Resolution of Oakland called for AAEV (termed here as Ebonics, specifically)"to be officially recognized as a language of African-Americans" (Coulmas, 2005, p.213).

\section{Conclusions}

This study aimed to underline the unique language form traits of African-American English Vernacular. It focused on this variety in terms of different theories concerning its origin and provided a relatively detailed description of the structure of this dialect. Furthermore, the study attempted to discuss the most common educational controversies surrounding the use of this particular variety of American English. Keeping the above-mentioned goals in mind, the following conclusions may be summarized:

1. Although a strong correlation exists between SAE and AAEV, the latter's origins are still widely debatable.

2. Creole langue forms spoken throughout the world have similar traits as AAEV in terms of lexicon, pronunciation and grammatical structure.

3. Phonology aspects distinguish AAEV from SAE through the changing of certain diphthong forms to monophthongs, failure to use dental fricatives, realization of final ' $n g$ ', final consonant cluster reduction, aspect marking, remote phase marker, and negation.

4. AAEV and SAE, particularly informal SAE, use the same lexicon, pronunciation and grammatical structure in many cases.

5. AAEV's anti-assimilation to SAE any other standard-language forms is the result of societal processes of segregation that forged pride, solidarity and a sense of identity among African-Americans.

6. AAEV -users are typically bi-dialectal, using both SAE and AAEV through code-switching.

7. The practice of code-switching adaption applies linguistically in different social settings.

8. AAEV usage has been met with controversy from representatives from the educational community. Its usage in public schools and society in general has been strongly debated.

9. Some representatives from the educational community have officially called for AAEV to be considered an official language for the African-American community.

10. Despite all the controversies surrounding AAEV in terms of its origin or educational role in America today, it might be safe to propose that this particular dialect of American English-call it what you wish-will only receive more attention in modern linguistics and acquire gradual socio-linguistic prestige in the $21^{\text {st }}$ century. This assumption is primarily based on the overwhelming political changes in the United States today.

\section{References}

Coulmas, F. (2005). Socio-linguistics: The study of speakers' choices. Cambridge: Cambridge University Press.

Dillard, J. L. (1972). Black English: Its history and usage in the United States. New York: Random House.

Green, L. J. (2002). African-American English: A linguistic introduction. Cambridge: Cambridge University Press. http://dx.doi.org/10.1017/CBO9780511800306

Green, L. J. (2000). Aspectual be-type constructions and coercion in African- American English. Natural Language Semantics, 8(1), 1-25. http://dx.doi.org/10.1023/A:1008392112529

Howe, D. \& Walker, J. (2000). Negation and the Creole-origins hypothesis: Evidence from early African-American English. In Poplack, S. The English History of African-American English, 109-139.

Labov, W.(2001). Principles of linguistic change. II: Social factors. Oxford: Blackwell. http://dx.doi.org/10.1002/9781444327496

Labov, W. (1997). Some further steps in narrative analysis. Journal of Narrative and Life History, 7(1), 395-415. http://dx.doi.org/10.1075/jnlh.7.49som

Labov, W. (1972). Language in the inner city: Studies in Black English Vernacular. Philadelphia: University of Pennsylvania Press 
Poplack, S. \& Tagliamonte, S. (2006). African-American English in the Diaspora. London: Blackwell. http://dx.doi.org/10.1075/veaw.g11.07pop

Pullum, G. K. (1997). Language that dare not speak its name. Nature, 386(1), $321-322$. http://dx.doi.org/10.1038/386321a0

Quinn, D. B., (1982). First Colonists: Documents on the Planting of the First English Settlements in North America, 1584-1590. Raleigh: North Carolina Department of Cultural Resources.

Rickford, J. (1999). African-American Vernacular English. London: Blackwell.

Smitherman, G. (1977). Talkin and Testifyin: The language of Black America. Boston: Houghton-Mifflin.

Stewart, W. (1975).Teaching blacks to read against their will. In Luelsdorff, P.A., Linguistic perspectives on Black English. Regensburg, Germany: Hans-Carl.

Wardhaugh, R. (2002). An introduction to Socio-linguistics. London: Blackwell.

Winford, D. (1992). Back to the past: The BEV/Creole connection revisited. Language Variation and Change, 4(3), 311-357. http://dx.doi.org/10.1017/S0954394500000831

Yule, G. (1985). The study of language. Cambridge: Cambridge University Press. http://dx.doi.org/10.1017/CBO9780511819742 